\title{
PERLINDUNGAN HUKUM TERHADAP WHISTLEBLOWER PADA TINDAK PIDANA KORUPSI BERDASARKAN UNDANG-UNDANG NOMOR 31 TAHUN 2014 TENTANG PERLINDUNGAN SAKSI DAN KORBAN
}

\author{
Oleh : \\ Juniar Hartikasari, S.Pd., SH., MH \\ (Dosen Tetap Sekolah Tinggi Ilmu Hukum Sumpah Pemuda)
}

\begin{abstract}
ABSTRAK
Dalam mengungkapkan kasus tindak pidana korupsi dibutuhkan saksi yang mengetahui keterlibatan seseorang khususnya dalam kasus korupsi, akan tetapi untuk menjadi seorang saksi yang mau bekerja sama dengan pihak penegak hukum tentunya tidak mudah karena semua itu beresiko tinggi. Salah satu saksi yang sangat dibutuhkan dala mengungkapkan kasus tindak pidana korupsi tersebut adalah whistle blower.

Whistleblower biasanya ditujukan kepada seseorang yang pertama kali mengungkap atau melaporkan suatu tindak pidana atau tindakan yang dianggap ilegal di tempatnya bekerja atau orang lain berada, kepada otoritas internal organisasi atau kepada publik seperti media massa atau lembaga pemantau publik. Pengungkapan tersebut tidak selalu didasari itikad baik sang pelapor, tetapi tujuannya untuk mengungkap kejahatan atau penyelewengan yang diketahuinya,sehingga adanya whistle blower dapat memutus rantai dari tindak pidana korupsi dan mafia hukum, sehinngga sangat wajar jika whistle wobber mendapat perlindungan hukum. Perlindungan terhadap rasa aman yang dapat diberikan kepada Whistleblower dapat berupa perlindungan terhadap fisik dan psikis mereka.
\end{abstract}

\begin{abstract}
In disclosing cases of corruption it requires witnesses who know someone's involvement, especially in cases of corruption, but to become a witness who is willing to cooperate with law enforcement is certainly not easy because they are at high risk. One witness that is badly needed in revealing a case of corruption is a whistle blower.

Whistleblowers are usually aimed at someone who first discloses or reports a criminal act or an act that is considered illegal in the place where they work or someone else is located, to the internal authority of the organization or to the public such as the mass media or public monitoring institutions. Such disclosure is not always based on the reporter's good intentions, but the purpose is to uncover known crime or fraud, so that the existence of a whistle blower can break the chain of corruption and the legal mafia, so it is only natural that whistle wobber get legal protection. The protection of the security that can be given to the Whistleblower can be in the form of physical and psychological protection
\end{abstract}




\section{A. Latar Belakang}

Hukum merupakan keseluruhan peraturan hidup yang bersipat memaksa untuk melindungi kepentingan manusia di masyarakat.Sasaran hukum yang hendak dituju bukan saja orang yang nyata-nyata berbuat melawan hukum, melainkan perbuatan yang mungkin akan terjadi, dan kepada alat perlengkapan negara untuk bertindak menurut hukum. Hukum sebagai instrumen pengatur dalam masyarakat selama ini diakui otoritasnya. ${ }^{21}$ Hukum menetapkan apa yang harus dilakukan dan apa saja yang tidak boleh dilakukan. Dalam melaksanakan peranan pentingnya bagi masyarakat hukum mempunyai fungsi seperti penertiban pengaturan, penyelesaian pertikaian dan sebagainya. ${ }^{22}$ Sasaran hukum yang hendak dituju bukan saja orang yang nyata-nyata berbuat melawan hukum, melainkan perbuatan yang mungkin akan terjadi, dan kepada alat perlengkapan negara untuk bertindak menurut hukum

Salah satu perbuatan melawan hukum yang merugikan negara adalah masalah tindak pidana korupsi. Selama ini istilah korupsi mengacu pada berbagai aktivitas atau tindakan secara tersembunyi dan illegal untuk mendapatkan keuntungan demi kepentingan pribadi atau golongan. ${ }^{23}$ Beberapa pengertian korupsi, disebutkan bahwa:

1. Korup artinya busuk, suka menerima uang suap/sogok, memakai kekuasaan untuk kepentingan sendiri dan sebagainya

2. Korupsi artinya perbuatan busuk seperti penggelapn uang, penerima uang sogok dan sebagainya

3. Koruptor adalah orang yang melakukan korupsi. ${ }^{24}$

Dengan demikian arti korupsi adalah sesuatu yang busuk,jahat dan merusak, berdasarkan kenyataan tersebut perbuatan korupsi menyangkut sesuatu yang bersipat amoral, sipat dan keadaan yang busuk, menyangkut jabatan instansi atau aparatur pemerintah, penyelewengan kekuasaan dalam jabatan karena pemberian,

${ }^{21}$ Trianto \& Titik triwulan Tutik, Bunga Rampai Hakikat Keilmuan,Prestasi Pustaka, Jakarta, 2007,hal.53

\footnotetext{
2012,hal.154

23 Chaerudin,Syaiful Ahmad Dinar,Syarif Fadilah, Tindak Pidana Korupsi,Refika Aditama,Jakarta,2009, hal.2

${ }^{24}$ Kementerian Pendidikan dan Kebudayaan Republik Indonesia, Pendidikan Anti Korupsi Untuk Perguruan Tinggi, 2011, hal. 24
}

${ }^{22}$ Soerjono Dirdjosisworo,Pengantar Ilmu Hukum,, PT.Raja Grapindo Persada, Jakarta, 
menyangkut faktor ekonomi dan politik dan penempatan keluarga atau golongan kedalam kedinasan di bawah kekuasaan jabatan. ${ }^{25}$ Sedangkan pengertian tindak pidana ialah perbuatan melakukan atau tidak melakukan sesuatu yang oleh peraturan perundang-undangan dinyatakan sebagai perbuatan yang dilarang dan diancam dengan pidana. ${ }^{26}$

Pengertian tindak pidana korupsi Menurut Pasal 2 ayat (1) UU No. 20 Tahun 2001, Tentang Pemberantasan Tindak Pidana Korupsi, disebutkan :

" Setiap orang baik pejabat pemerintah maupun swasta yang secara melawan hukum melakukan perbuatan memperkaya diri sendiri atau korporasi yang dapat merugikan keuangan negara atau perekonomian negara, dipidana dengan pidana penjara seumur hidup atau pidana penjara paling singkat 4 (empat) tahun dan paling lama 20 (dua puluh) tahun dan atau denda paling sedikit Rp.200.000.000,00 (dua ratus juta) dan paling banyak Rp.1.000.000.000,00 (satu miliar rupiah)."

Dalam mengungkapkan kasus tindak pidana korupsi dibutuhkan saksi yang mengetahui keterlibatan seseorang khususnya dalam kasus korupsi, akan tetapi untuk menjadi seorang saksi yang mau bekerja sama dengan pihak penegak hukum tentunya tidak mudah karena semua itu beresiko tinggi. Salah satu saksi yang sangat dibutuhkan dala mengungkapkan kasus tindak pidana korupsi tersebut adalah whistle blower.

Pengertian whistle blower secara yuridis dapat ditemukan pada Surat Edaran Mahkamah Agung (SEMA) Nomor 4 Tahun 2011 tentang Perlakuan bagi Whistleblower dan Justice Collaborator.Pada SEMA tersebut, Justice Collaborator dimaknai sebagai seorang pelaku tindak pidana tertentu, tetapi bukan pelaku utama, yang mengakui perbuatannya dan bersedia menjadi saksi dalam proses peradilan.

Sedangkan menurut Lembaga Perlindungan Saksi dan Korban, untuk disebut sebagai whistle blower, saksi tersebut setidaknya harus memenuhi dua kriteria mendasar:

Kriteria pertama, whistle blower menyampaikan atau mengungkap laporan kepada otoritas yang berwenang atau kepada media massa atau publik. Dengan mengungkapkan kepada otoritas yang berwenang atau media massa diharapkan dugaan suatu kejahatan dapat diungkap dan terbongkar.

\footnotetext{
${ }^{25}$ Ibid

${ }^{26}$ Barda Nawawi Arief,Kebijakan Hukum Pidana,Prenada Media Group,Jakarta,2010, hal.79
} 
Kriteria kedua, seorang whistle blower merupakan orang 'dalam', yaitu orang yang mengungkap dugaan pelanggaran dan kejahatan yang terjadi di tempatnya bekerja atau ia berada. Karena skandal kejahatan selalu terorganisir, maka seorang whistle blower kadang merupakan bagian dari pelaku kejahatan atau kelompok mafia itu sendiri. Dia terlibat dalam skandal lalu mengungkapkan kejahatan yang terjadi. ${ }^{27}$

Di Indonesia sendiri peradaban mengenai whistleblower masih sangat jauh dari perhatian masyarakat dan para penegak hukum. Itu bisa dilihat dari aturan atau perundang-undangan yang mengatur mengenai bentuk perlindungan terhadap whistleblower. Padahal whistleblower memiliki peranan yang sangat penting dalam terungkapnya kasus-kasus korupsi yang di lakukan dan telah terbukti eksistensinya dalam mengungkap kasus-kasus korupsi.

Adapun salah satu contoh Whistle Blower di Indonesia adalah :

Jakarta - Terpidana kasus korupsi pengamanan Pilgub Jabar dan perkara PT

Salmah Arowana Lestari (SAL), Susno Duadji dieksekusi tim jaksa dari Kejaksaan Tinggi DKI yang dibantu Kejati Jabar dan Kejari Bandung. Eksekusi mantan Kabareskrim tersebut berlangsung panas. Pengacara Susno bahkan sesumbar pengawal Susno akan menembak siapa pun yang berani mengeksekusi bosnya. Selain dua kasus di atas, sejumlah kasus lain juga menunjukan dugaan keterlibatan Susno di dalamnya. Mulai dari kasus 'Cicak versus Buaya', bailout Bank Century, kasus pembunuhan yang melibatkan Antasari Azhar sebagai terdakwa dalam pembunuhan Nasrudin Zulkarnaen, hingga mafia pajak Gayus Tambunan. Susno bahkan sempat 'melawan' institusinya sendiri karena mengungkap modus makelar proyek di tubuh Polri hingga akhirnya dia ditetapkan sebagai Whistle Blower.

Rangkaian panjang perjalanan kasus Susno Duadji berujung pada vonis pengadilan yang dijatuhkan atasnya hingga upaya eksekus.. ${ }^{28}$

Terhadap salah satu contoh kasus di atas ketika dia melaporkan dugaan praktik korupsi tapi kenyataannya justru dia yang dijadikan tersangka yang justru dipidana karena laporannya sendiri. Melihat beratnya resiko yang akan dihadapi whistleblower, cukup beralasan bila baru segilintir orang yang berani menjadi whistleblower pada tindak pidana korupsi. Logikanya terdapat banyak orang yang mengetahui suatu skandal, penyimpangan, atau korupsi yang terjadi di lingkungannya tetapi memilih berdiam diri daripada buka mulut, karena jaminan

27 Lembaga Perlindungan Saksi dan Korban,Memahami Whistleblower, Lembaga Perlindungan Saksi dan Korban (LPSK), Jakarta, 2011. hal 1-2.

${ }^{28}$ https://robiatuladawiyah995.wordpress.com/2015/12/21/contoh-kasus-whistle-blowing-diindonesia/,diakses tanggal 14 Mei 2019 
perlindungan hukum dan keamanan belum tentu bisa di peroleh. Perlindungan hukum dapat diartikan sebagai setiap bentuk perlindungan yang diatur dan didasarkan oleh peraturan perundang-undangan berdasarkan kepastian hukum. ${ }^{29}$

\section{B. Permasalahan}

Dari apa yang telah diuraikan dalam latar belakang di atas, maka Permasalahan yang di ambil dalam penulisan ini adalah bagaimana perlindungan hukum terhadap whistleblower pada tindak pidana korupsi berdasarkan UndangUndang Nomor 31 Tahun 2014 Tentang Perlindungan Saksi dan Korban?

\section{Pembahasan}

Keberadaan Whistle Blower merupakan peran penting dalam mengungkapkan kasus tindak pidana korupsi.. Whistleblower biasanya ditujukan kepada seseorang yang pertama kali mengungkap atau melaporkan suatu tindak pidana atau tindakan yang dianggap ilegal di tempatnya bekerja atau orang lain berada, kepada otoritas internal organisasi atau kepada publik seperti media massa atau lembaga pemantau publik. Pengungkapan tersebut tidak selalu didasari itikad baik sang pelapor, tetapi tujuannya untuk mengungkap kejahatan atau penyelewengan yang diketahuinya,sehingga adanya whistle blower dapat memutus rantai dari tindak pidana korupsi dan mafia hukum, sehinngga sangat wajar jika whistle wobber mendapat perlindungan hukum.

Perlindungan terhadap rasa aman yang dapat diberikan kepada Whistleblower dapat berupa perlindungan terhadap fisik dan psikis mereka. Perlindungan fisik dan psikis tersebut tidak hanya diberlakukan untuk keamanan pribadi berupa perlindungan dari segala macam ancaman, teror, kekerasan, tekanan, gangguan terhadap diri, jiwa dan harta mereka dari pihak manapun, namun juga harus meliputi jaminan perlindungan fisik dan psikis bagi keluarga mereka. ${ }^{11}$

Adapun bentuk-bentuk perlindungan hukum yang diberikan oleh Pengadilan bagi seorang yang berperan sebagai Whistle-Blower, yaitu

\footnotetext{
${ }^{29}$ Faisal, ,Menerobos Positivisme Hukum, Gramata Publishing, Bekasi, 2012, hal. 73

${ }^{11}$ Hamdan, ,Alasan Penghapus Pidana. Teori dan Studi Kasus, Refika Adita,Bandung, 2012,hal. 
1. Memberikan penghargaan berupa peringanan ancaman hukuman pidana. Besarnya peringanan yang diberikan ini ditentukan dari hasil musyawarah para hakim

2. Dalam masa penahanan Pengadilan memberikan tempat atau ruangan yang nyaman dan terhindar dari berbagai macam ancaman

3. Pada saat proses pemeriksaan tahap interogasi terhadap whistle-blower dilakukan dengan menjaga harkat dan martabatnya, diperlakukan secara baik dan tidak semena-mena. $^{12}$

Tidak banyak orang yang bersedia mengambil resiko untuk menjadi whistle blower dan mengungkapkan fakta suatu tindak pidana korupsi jika dirinya, keluarganya dan harta bendanya tidak mendapat perlindungan dari ancaman yang mungkin timbul karena pengungkapan kasus tersebut. Begitu pula dengan saksi, jika tidak mendapat perlindungan yang memadai, akan enggan memberikan keterangan sesuai dengan fakta yang dialami, dilihat, dan dirasakannya sendiri.

Saksi dalam peradilan pidana menempati posisi kunci, sebagaimana terlihat dalam penempatannya dalam Pasal 184 KUHAP. Sebagai alat bukti utama, tentu dampaknya sangat terasa bila dalam suatu perkara tidak diperoleh saksi. Pentingnya kedudukan saksi dalam proses peradilan pidana, telah dimulai sejak awal proses peyelidikan dalam peradilan pidana. Begitu pula dalam proses selanjutnya, ditingkat penyidikan, penuntutan sampai pada pemeriksaan di pengadilan, keterangan saksi sebagai alat bukti utama menjadi acuan hakim dalam memutus bersalah atau tidaknya terdakwa.

Perlindungan terhadap whistle blower diatur dalam Pasal 10 Undang-undang No. 31 Tahun 2014 tentang Perlindungan Saksi dan Korban sebagai berikut :

1) Saksi, Korban dan Pelapor tidak dapat dituntut secara hukum baik pidana maupun perdata atas laporan, kesaksian yang akan, sedang, atau telah diberikannya, kecuali kesaksian atau laporan tersebut diberikan tidak dengan itikad baik.

2) Dalam hal terdapat tuntutan hukum terhadap saksi, korban, saksi pelaku dan/atau pelapor atas kesaksian, dan/atau laporan yang akan, sedang atau telah diberikan, tuntutan hukum tersebut wajib ditunda hingga kasus yang ia laporkan atau ia

\footnotetext{
${ }^{12}$ Ibid
} 
berikan kesaksian telah diputuskan pengadilan dan memperoleh kekuatan hukum tetap.

Sedangkan Surat Edaran Mahkamah Agung (SEMA) No.04 tahun 2011 tentang perlakuan bagi pelapor tindak pidana (whistleblower) dan saksi pelaku yang bekerjasama (justice collaborators)di dalam perkara tindak pidana tertentu mengatur perlindungan terhadap whistle blower tersebut yaitu terdapat dalam Surat Edaran Mahkamah Agung (SEMA) No.04 tahun 2011 angka (1), (2) dan (7 )yang berbunyi :

(1) Tindak pidana tertentu yang bersifat serius seperti tindak pidana korupsi, terorisme, tindak pidana pencucian uang, perdagangan orang, maupun tindak pidana, lainnya yang bersifat terorganisir, telah menimbulkan masalah dan ancaman yang serius terhadap stabilitas seta nilai-nilai demokrasi, etika, dan keadilan serta membahayakan pembangunan berkelanjutan dan supermasi hukum.

(2) Dalam upaya menumbuhkan partisipasi public guna mengungkap tindak pidana sebagaimana dimaksud dalam butir kesatu diatas, harus diciptakan iklim yang kondusif antara lain dengan cara memberikan perlindungan hukum serta perlakuan khusus kepada setiap orang yang mengetahui, melaporkan, dan atau menemukan suatu hal yang dapat membantu aparat penegak hukum untuk mengungkap dan menangani tindak pidana dimaksud secara efektif.

(7) Dengan merujuk pada nilai-nilai di dalam ketentuan tersebut diatas dengan ini Mahkamah Agung meminta kepada para Hakim agar jika menemukan tentang adanya orang-orang yang dapat dikatagorikan sebagai Pelapor Tindak Pidana dan Saksi Pelaku yang Bekerjasama dapat memberikan perlakuan khusus dengan antara lain memberikan keringanan pidana dan atau bentuk perlindungan lainnya.

Perlindungan hukum dapat berupa kekebalan yang diberikan kepada pelapor dan saksi untuk tidak dapat digugat secara perdata atau dituntut secara pidana sepanjang yang bersangkutan memberikan kesaksian atau laporan dengan itikad baik atau yang bersangkutan tidak sebagai pelaku tindak pidana itu sendiri. Dan apabila ada tuntutan hukum terhadap pelapor maka laporan tersebut wajib ditunda hingga 
kasus yang ia laporkan atau ia berikan kesaksian telah diputuskan pengadilan dan memperoleh kekuatan hukum tetap.

\section{Penutup}

\section{Kesimpulan}

Perlindungan terhadap whistle blower diatur dalam Pasal 10 Undangundang No. 31 Tahun 2014 tentang Perlindungan Saksi dan Korban sebagai berikut :

1) Saksi, Korban dan Pelapor tidak dapat dituntut secara hukum baik pidana maupun perdata atas laporan, kesaksian yang akan, sedang, atau telah diberikannya, kecuali kesaksian atau laporan tersebut diberikan tidak dengan itikad baik.

2) Dalam hal terdapat tuntutan hukum terhadap saksi, korban, saksi pelaku dan/atau pelapor atas kesaksian, dan/atau laporan yang akan, sedang atau telah diberikan, tuntutan hukum tersebut wajib ditunda hingga kasus yang ia laporkan atau ia berikan kesaksian telah diputuskan pengadilan dan memperoleh kekuatan hukum tetap.

Sedangkan Surat Edaran Mahkamah Agung (SEMA) No.04 tahun 2011 tentang perlakuan bagi pelapor tindak pidana (whistleblower) dan saksi pelaku yang bekerjasama (justice collaborators)di dalam perkara tindak pidana tertentu mengatur perlindungan terhadap whistle blower tersebut yaitu terdapat dalam Surat Edaran Mahkamah Agung (SEMA) No.04 tahun 2011 angka (1), (2) dan (7) yang berbunyi :

(1) Tindak pidana tertentu yang bersifat serius seperti tindak pidana korupsi, terorisme, tindak pidana pencucian uang, perdagangan orang, maupun tindak pidana, lainnya yang bersifat terorganisir, telah menimbulkan masalah dan ancaman yang serius terhadap stabilitas seta nilai-nilai demokrasi, etika, dan keadilan serta membahayakan pembangunan berkelanjutan dan supermasi hukum. 
(2) Dalam upaya menumbuhkan partisipasi public guna mengungkap tindak pidana sebagaimana dimaksud dalam butir kesatu diatas, harus diciptakan iklim yang kondusif antara lain dengan cara memberikan perlindungan hukum serta perlakuan khusus kepada setiap orang yang mengetahui, melaporkan, dan atau menemukan suatu hal yang dapat membantu aparat penegak hukum untuk mengungkap dan menangani tindak pidana dimaksud secara efektif.

(7) Dengan merujuk pada nilai-nilai di dalam ketentuan tersebut diatas dengan ini Mahkamah Agung meminta kepada para Hakim agar jika menemukan tentang adanya orang-orang yang dapat dikatagorikan sebagai Pelapor Tindak Pidana dan Saksi Pelaku yang Bekerjasama dapat memberikan perlakuan khusus dengan antara lain memberikan keringanan pidana dan atau bentuk perlindungan lainnya.

\section{E. Saran - saran}

1. Saat ini belum ada peraturan perundang-undangan yang spesifik mengatur perlindungan terhadap whistleblower dan hendaknya ada peraturan khusus yang mengatur perlindungan terhadap Whistleblower tersebut

2. Beberapa bentuk perlindungan yang telah ada dan telah diberikan kepada WhistleBlower, pelaksanaannya lebih optimal dan lebih baik lagi sehingga pemberian perlindungan terhadap Whistle-Blower tersebut mendapatkan apresiasi yang lebih baik lagi.

\section{DAFTAR PUSTAKA}

Barda Nawawi Arief,Kebijakan Hukum Pidana,Prenada Media Group,Jakarta,2010

Chaerudin,Syaiful Ahmad Dinar,Syarif Fadilah, Tindak Pidana Korupsi,Refika Aditama,Jakarta,2009

Faisal, ,Menerobos Positivisme Hukum , Gramata Publishing, Bekasi, 2012

Kementerian Pendidikan dan Kebudayaan Republik Indonesia, Pendidikan Anti Korupsi Untuk Perguruan Tinggi, 2011 
Lembaga Perlindungan Saksi dan Korban,Memahami Whistleblower, Lembaga Perlindungan Saksi dan Korban (LPSK), Jakarta, 2011

Soerjono Dirdjosisworo,Pengantar Ilmu Hukum,, PT.Raja Grapindo Persada, Jakarta, 2012

Trianto \& Titik triwulan Tutik, Bunga Rampai Hakikat Keilmuan,Prestasi Pustaka, Jakarta, 2007 